\title{
Nerve Growth Factor Receptors on Chick Embryo Sympathetic Ganglion Cells: Binding Characteristics and Development
}

\author{
Earl W. Godfrey and Eric M. Shooter \\ Department of Neurobiology, Stanford University School of Medicine, Stanford, California 94305
}

\begin{abstract}
NGF is essential for the development and maintenance of sympathetic and certain sensory neurons. The NGF receptors on the surface of sympathetic ganglion cells from chick embryos were characterized; they consist of high-affinity receptors with a dissociation constant of about $10^{-11} \mathrm{M}$, and low-affinity receptors with a dissociation constant of about $10^{-9} \mathrm{M}$. There are more than 10 times as many low-affinity as high-affinity receptors per cell. The heterogeneity of NGF binding is not due to negatively cooperative interactions among the receptors. The highand low-affinity components of NGF binding defined at steady state correspond to slowly and rapidly dissociating components of bound NGF seen in kinetic experiments. In addition, a very slowly dissociating component of bound NGF was observed; this component was a small fraction of binding at low concentrations of NGF but increased to $20-60 \%$ of bound NGF at the highest NGF concentrations examined. This very slowly dissociating component of bound NGF accounts for several peculiarities in the binding data not accounted for by steady-state binding of NGF to its high- and low-affinity receptors.

Developmental studies showed that both high- and low-affinity NGF receptors were present on chick embryo sympathetic ganglion cells from 6.5 to $20 \mathrm{~d}$ in ovo. No significant differences in the numbers or affinities of the receptors were seen with cells from ganglia at 9,11 , or $15 \mathrm{~d}$ of development. Cultured non-neuronal cells from sympathetic ganglia had only low-affinity NGF receptors.
\end{abstract}

NGF is a polypeptide hormone involved in many aspects of the development and maintenance of sympathetic and sensory neurons (Greene and Shooter, 1980; Thoenen and Barde, 1980). The first step in the interaction of NGF with these neurons is its binding to specific plasma membrane receptors (Yankner and Shooter, 1982). Frazier et al. (1974) described heterogeneity of NGF binding to chick embryo sympathetic and sensory ganglion cells, and they attributed it to negatively cooperative interactions among receptors. More recently, Sutter el al. (1979a, b) showed that the NGF receptors on chick sensory ganglion cells did not interact in a negatively cooperative manner. Instead, 2 major classes of NGF receptors with dissociation constants $\left(K_{\mathrm{d}}\right)$ of about $10^{-11}$ and $10^{-9} \mathrm{M}$ were defined. These 2 classes of NGF receptors have also been seen in membrane preparations from sensory ganglia (Riopelle et al., 1980), and

\footnotetext{
Received Oct. 3, 1985; revised Feb. 20, 1986; accepted Feb. 24, 1986.

This work was supported by grants from the National Institute of Neurological and Communicative Disorders and Stroke (NS 04270) and the American Cancer Society (BC 325) E.W.G. was supported by National Research Service Award NS 05803 from the NIH. We wish to thank Sandra Hernández, William Stroud, and Michael Ignatius for technical assistance in dissecting embryonic ganglia, and Drs. Arne Sutter, Tony Young, Gary Landreth, Astrid Zimmermann, and David Estell for helpful discussions.

Correspondence should be addressed to Dr. Earl W. Godfrey, Department of Anatomy and Cellular Biology, Medical College of Wisconsin, 8701 Watertown Plank Road, Milwaukee, WI 53226.

Copyright (c) 1986 Society for Neuroscience $0270-6474 / 86 / 092543-08 \$ 02.00 / 0$
}

they seem to correspond to polypeptides of 2 different molecular weights identified in cross-linking experiments with ${ }^{125} \mathrm{I}-\beta \mathrm{NGF}$ (Hosang and Shooter, 1985). Olender and Stach (1980) also demonstrated these 2 classes of NGF receptors on sympathetic ganglion cells from chick embryos and found that some of the bound NGF is very slowly dissociable or "sequestered" in these cells. Here, we characterize in detail binding to the high- and low-affinity NGF receptors on embryonic chick sympathetic ganglion cells by a variety of steady-state and kinetic measurements, and we show that the heterogeneity of binding is not due to negatively cooperative interactions among NGF receptors. We also demonstrate a very slowly dissociating component of bound NGF and propose that this component is generated in large part from NGF initially bound to low-affinity receptors.

Although subpopulations of chick embryo sympathetic ganglion neurons depend on different growth factors, including NGF, for survival in culture (Edgar et al., 1981), all neurons cultured from 7,12 , and $16 \mathrm{~d}$ embryonic ganglia possess high-affinity NGF receptors, as shown by autoradiography of bound ${ }^{125} \mathrm{I}-$ $\beta$ NGF (Rohrer et al., 1983). In order to determine if both highand low-affinity NGF receptors are present on chick embryo sympathetic ganglion cells throughout their development, and if the numbers or affinities of these receptors change during development, we examined steady-state binding of ${ }^{125} \mathrm{I}-\beta \mathrm{NGF}$ to cells from ganglia at days 6.5-20 of incubation. A preliminary report of these results has been made (Godfrey and Shooter, 1979).

\section{Materials and Methods}

\section{Materials}

Fertilized chicken eggs (DeKalb-Webster Sex-linked Red) were obtained from A\&M Hatchery (Santa Rosa, CA), and were incubated at $39^{\circ} \mathrm{C}$ in a humidified incubator. Embryos were staged according to Hamilton (1952). Protamine sulfate and lactoperoxidase were obtained from Sig$\mathrm{ma}$, and $\mathrm{Na}^{125}$ I (carrier-frec, $\mathrm{pH}$ 8-11) was from Amersham/Scarlc. The $\beta$ subunit ( $\beta N$ GF) was prepared as described by Moore and Shooter (1975). Centriflo CF50A filters were obtained from Amicon Corp. Trypsin (TRTPCK), DNase (DP), and soybean trypsin inhibitor (SI) were purchased from Worthington, fetal calf serum from Irvine Scientific, and BSA (Pentex fraction V) from Miles.

\section{Iodination of $\beta N G F$}

Iodination of $\beta$ NGF was carried out by the lactoperoxidase method as described by Sutter et al. (1979a). Specific radioactivity of the preparations used was $58.8 \pm 13 \mathrm{cpm} / \mathrm{pg}$. In fresh preparations, acid precipitability was $92-98 \%$. Each preparation was used for 4 weeks or less; during this time acid precipitability fell to about $85 \%$.

\section{Dissociation of ganglia}

Sympathetic ganglia were removed from the lumbosacral region of 6.5$20 \mathrm{~d}$ chick embryos. Ganglia were kept in ice cold Dulbecco's PBS (Dulbecco and Vogt, 1954), with $1 \mathrm{~g} /$ liter glucose without $\mathrm{Ca}$ or $\mathrm{Mg}$ for up to 3-4 hr, then cleaned of adhering connective tissue with forceps and countcd. Ganglia were then exposed to $0.01 \%$ trypsin $(0.1 \%$ for 

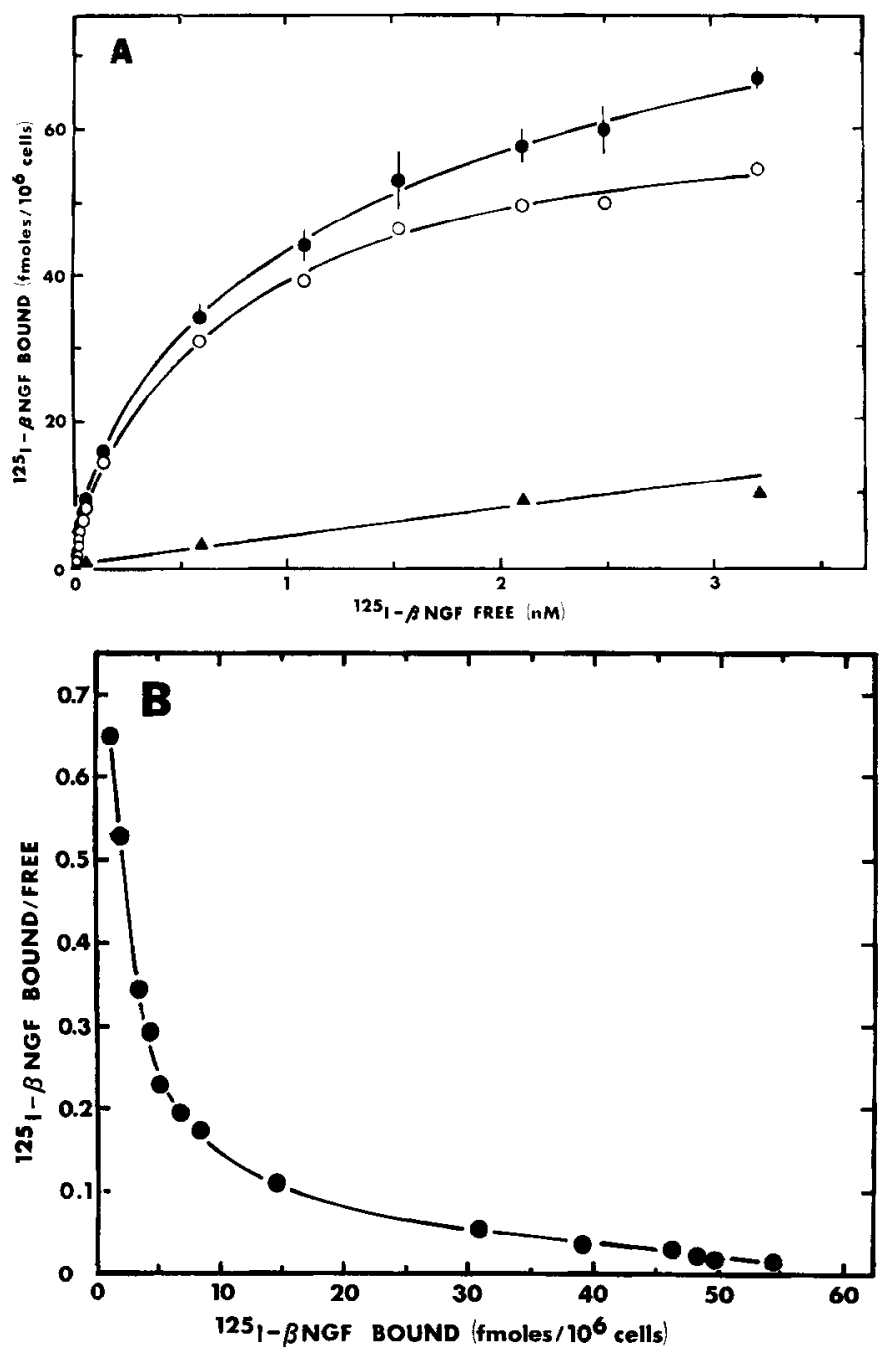

Figure 1. Steady-state binding of ${ }^{125} \mathrm{I}-\beta \mathrm{NGF}$ to sympathetic ganglion cells from $11 \mathrm{~d}$ chick embryos. Cells $\left(1.1 \times 10^{6} / \mathrm{ml}\right)$ were incubated $\left(37^{\circ} \mathrm{C}, 45 \mathrm{~min}\right)$ with $3.4 \times 10^{-12}$ to $3.3 \times 10^{-4} \mathrm{M}{ }^{125} \mathrm{I}-\beta \mathrm{NGF}$. Bound and free ${ }^{125}[-\beta N G F$ were separated by rapid centrifugation as described in Materials and Methods. The concentration of free ${ }^{125} I-\beta N G F$ was corrected for its acid precipitability $(10 \%$ trichloroacetic acid, $15 \mathrm{~min}$, $4^{\circ} \mathrm{C}$ ). $A$, Binding of ${ }^{125} \mathrm{I}-\mathrm{NGF}$ as a function of free ${ }^{125} \mathrm{I}-\beta \mathrm{NGF}$ concentration. Total $(\Theta)$, specific $(O)$, and nonspecific $(A)$ binding were measured in triplicate; bars indicate SD. $B$, Scatchard plot of data shown in $A$.

developmental studies and for embryos older than $11 \mathrm{~d}$ ) and $0.001 \%$ DNase in PBS without $\mathrm{Ca}$ or $\mathrm{Mg}$ for $10 \mathrm{~min}$ at $37^{\circ} \mathrm{C}$. Fetal calf serum (to $5 \% \mathrm{vol} / \mathrm{vol}$ ) and soybean trypsin inhibitor $(0.08 \mathrm{mg} / \mathrm{ml}$ ) were then added, and the ganglia were disrupted by forcing the suspension vig- orously through a 9 inch Pasteur pipette 30-40 times, until most visible pieces had disappeared. The cell suspension was then filtered through a double layer of Nylon mesh cloth ( $50 \mu \mathrm{m}$ pore size) to remove clumps. The yield of cells increased from 10,000/ganglion at day 8 to 40,000 / ganglion at day 14, then fell to 14,000 /ganglion at day 20 ; at day 11 , about 25,000 cells/ganglion (about $95 \%$ viable by Trypan blue exclusion) were obtained. Mechanical dissociation alone (day 9 ganglia) yiclded $10-20 \%$ fewer cells than trypsin dissociation, but cell viability fell to about $65 \%$.

\section{Binding assays}

The assays were similar to those used by Sutter et al. (1979a). Briefly, cells were centrifuged $(250 \times \mathrm{g}, 10 \mathrm{~min})$ and resuspended in PBS with $1 \mathrm{mg} / \mathrm{ml} \mathrm{BSA}$, then added to ${ }^{125}[-\beta \mathrm{NGF}$ diluted into the same solution in polystyrene tubes (Falcon). All incubations were carried out at $37^{\circ} \mathrm{C}$ unless otherwise stated. Cell concentrations were generally 1-2 $\times 10^{6} /$ ml. Steady-state measurements were made after 45 min incubation. Bound and free ${ }^{125} I-\beta$ NGF were separated by centrifugation $(10,000 \times$ $\mathrm{g}, 1 \mathrm{~min}$ ) of $0.1 \mathrm{ml}$ portions of cell suspension through a 2-step sucrose gradient $(0.225 \mathrm{ml})$ in $400 \mu \mathrm{l}$ tubes in a Beckman Microfuge (Herrup and Shooter, 1973). Tubes were then frozen in dry ice-ethanol, tips were cut off with a razor blade, and both tips and tops of tubes were counted in a Beckman Gamma 300 counter. Nonspecific binding was measured in the presence of a 100 -fold or greater excess of unlabeled $\beta \mathrm{NGF}$; a similar amount was added to initiate dissociation. "Tight" binding (see Results) was determined by measuring the amount of ${ }^{125}$ I$\beta N G F$ remaining bound to cells after dissociation in the presence of excess unlabeled $\beta \mathrm{NGF}$ at $0.5^{\circ} \mathrm{C}$ for $20-40 \mathrm{~min}$ (Landreth and Schooter, 1980). For "chase versus dilution" experiments, cells were incubated with ${ }^{125}[-\beta N G F$ until steady state was reached. Dissociation was then initiated by diluting $0.1 \mathrm{ml}$ portions of cell suspensions into $1.4 \mathrm{ml}$ PBS with $1 \mathrm{mg} / \mathrm{ml} \mathrm{BSA}$ (with or without unlabeled $\beta \mathrm{NGF}$ ) in $1.5 \mathrm{ml} \mathrm{Mi-}$ crofuge tubes. Samples were taken at various times by centrifuging cells in the Microfuge (10,000 $\times \mathrm{g}, 1 \mathrm{~min})$, aspirating the supernatant, cutting off the tip of the tube, and counting it. Some association experiments were carried out in modified F12 culture medium (Spooner, 1970) containing $25 \mathrm{~mm}$ Na-HEPES, $5 \mathrm{~mm} \mathrm{NaHCO}$, and $1 \%$ fetal calf serum. Results did not differ from those obtained when PBS and BSA was used. All binding assays were done in triplicate.

Non-neuronal cells were obtained by allowing cells from dissociated ganglia to attach to plastic tissue culture dishes coated with calf skin collagen (Calbiochem) for $\mathbf{4 5} \mathrm{min}$. Adherent cells were then cultured for 1-4 weeks in modified F12 medium (Spooner, 1970) with 5\% fetal calf serum with or without $20 \mathrm{ng} / \mathrm{ml} \beta N G F$. Medium was changed twice per week, and cells were subcultured in plastic dishes, following trypsin dissociation, when confluency was reached. Non-ncuronal cells were subcultured 2-4 times before use for binding assays. They were removed from culture dishes by incubation with $\mathrm{Ca}$-, $\mathrm{Mg}$-free PBS (sometimes with $2 \mathrm{~mm}$ EDTA) for $1-2.5 \mathrm{hr}$, followed by a combination of pipetting and scraping with a rubber policeman.

\section{Results}

\section{Steady-state binding}

The concentration dependence of the binding of ${ }^{125}[-\beta N G F$ to cells dissociated from sympathetic ganglia of $11 \mathrm{~d}$ chick embryos is shown in Figure $1 A$. Cells were exposed at $37^{\circ} \mathrm{C}$ to ${ }^{125} \mathrm{I}-\beta \mathrm{NGF}$ at concentrations of $3.4 \mathrm{pm}$ to $3.3 \mathrm{~nm}$ for $45 \mathrm{~min}$, at which time

\section{Table 1. NGF receptors of $11 \mathrm{~d}$ chick embryo sympathetic ganglion cells: steady-state and kinetic binding constants}

\section{Constant ${ }^{a}$}

$K_{\mathrm{d}}$ (concentration for half-maximal saturation, $\mathrm{M}$ )

$\boldsymbol{R}_{\mathrm{0}}$ (binding sites/cell)

$k_{+1}$ (association rate constant, $\mathrm{M}^{-1} \sec ^{-1}$ )

$k$, (dissociation rate constant, $\mathbf{s e c}^{-1}$ )
High-affinity receptors

$1.0 \pm 0.5 \times 10^{-11}$

$2100 \pm 980$

$8.7 \pm 2.3 \times 10^{7}$

$6.7 \pm 1.5 \times 10^{-4}$
Low-affinity receptors

$8.9 \pm 3.4 \times 10^{-10}$

$n$

$27,000 \pm 7500$

$10^{7}-10^{8 b}$

$10^{-1^{b}}$

5

5

2

10

${ }^{a}$ The steady-state constants shown are averages $( \pm \mathrm{SD})$ of constants derived by computer-fitting binding data (bound vs. free ${ }^{~}{ }^{2>I-\beta N G F)}$ with binding isotherms representing 2 classes of receptors according to the algorithm of Marquardt. Association rate constants were obtained by plotting association data as described in the legend of Figure $3 B$. Dissociation rate constants for the high-affinity receptors were calculated from linear least-squares fits to semilog plots (e.g., Fig. 2) of dissociation data obtained after preloading cells for $45 \mathrm{~min}$ with $7.7 \times 10^{-12} \mathrm{M}{ }^{123} \mathrm{I}-\beta \mathrm{NGF}$, a concentration at which $\geq 90 \%$ of the binding was tight ( $\geq 80 \%$ high affinity).

${ }^{b}$ Estimates; association and dissociation of ${ }^{125} \mathrm{I}-\beta \mathrm{NGF}$ and low-affinity receptors occur too rapidly to measure. 
steady state had been reached at all concentrations. Nonspecific binding (usually $10-20 \%$ of total binding at these concentrations) was subtracted, and the data were replotted according to the method of Scatchard (1949), as shown in Figure $1 B$. The biphasic Scatchard plot approaches linearity at both extremes of ${ }^{125} \mathrm{I}-\beta \mathrm{NGF}$ concentration, suggesting the presence of 2 classes of receptors with affinities for ${ }^{125} I-\beta N G F$ that differ by 2 orders of magnitude. The lower-affinity receptors are about 13 -fold more numerous than the higher-affinity receptors (Table 1). Similar affinity constants and site numbers were obtained when binding reached steady state at $0.5^{\circ} \mathrm{C}$ instead of $37^{\circ} \mathrm{C}$. Binding sites for ${ }^{125} \mathrm{I}-\beta \mathrm{NGF}$ on these cells were not completely saturated (Fig. $1 \mathrm{~A}$ ), even at ${ }^{125}$ I- $\beta$ NGF concentrations as high as $7.7 \times$ $10^{-9} \mathrm{M}$. At this concentration (about 9 times the $K_{\mathrm{d}}$ for lowaffinity receptors), one would expect nearly complete saturation of the receptors. Unfortunately, the increasing contribution of nonspecific binding prevented accurate assessment of binding at even higher concentrations of ${ }^{125}$ I- $\beta$ NGF. A small amount of degradation of ${ }^{125} \mathrm{I}-\beta \mathrm{NGF}$ occurred at the lowest concentrations of ligand used; only 5-15\% specific degradation (Layer and Shooter, 1983) was seen after 1 hr incubation of cells with $8 \times$ $10^{-12} \mathrm{M}^{123} \mathrm{I}-\beta \mathrm{NGF}$ at $37^{\circ} \mathrm{C}$. This did not significantly affect the concentration of free ligand and has thus been disregarded in our calculations, as have similarly small decreases in steadystate binding and cell viability during the furst hour of incubation.

A 10 min incubation of the ganglia in $0.01 \%$ trypsin was necessary to obtain the maximal number of viable dissociated cells. The effects of this trypsin treatment on the NGF receptors were assayed in 2 ways. First, cells were dispersed either by mechanical disruption or by trypsin treatment of ganglia from $9 \mathrm{~d}$ embryos. The number of receptors per cell was $50-200 \%$ larger in the preparations of mechanically dispersed cells. This was probably due both to the lower cell yield from mechanical dispersion (which probably produced more membrane fragments) and to the trypsin lability of both classes of receptors. However, the affinities $\left(K_{d} s\right)$ and the ratios of high- and lowaffinity sites per cell were not significantly different in the cells from the 2 preparations. Second, ganglia from $11 \mathrm{~d}$ embryos were dissociated using trypsin, and the cells further incubated in trypsin before inhibitors were added. The number of both high-and low-aflinity NGF receptors fell $30-40 \%$ with a further 10 min trypsin treatment after dissociation. These data should not be confused with those of Landreth and Shooter (1980), who showed that high-affinity receptors on PC12 pheochromocytoma cells are preferentially protected from degradation by trypsin, but only following binding by NGF. While both classes of NGF receptors on sympathetic ganglion cells appear to be inactivated by trypsin, the rates of inactivation are similar for the 2 sites, and thus the ratio of high-and low-affinity receptors measured on cells exposed to trypsin should be correct. Furthermore, estimates of receptor numbers on thesc ccll bodics are probably only $30-40 \%$ below actual values in vivo.

\section{Kinetics of dissociation and association}

Dissociation of ${ }^{125} I-\beta N G F$ from its receptors was observed after addition of a large excess of unlabeled $\beta$ NGF to a suspension of cells and ${ }^{125} \mathrm{I}-\beta \mathrm{NGF}$ after steady-state binding had been reached. At low concentrations of ${ }^{125} \mathrm{I}-\beta \mathrm{NGF}$, binding should occur mainly at high-affinity sites. As expected, dissociation curves at these low concentrations consisted almost entirely of a slowly dissociating component (half-time for dissociation of about $17 \mathrm{~min}$ ) with simple first-order kinetics (Fig. 2, filled circles). The dissociation rate constant for the high-affinity receptors was $6.7( \pm 1.5) \times 10^{-4} \mathrm{sec}^{-1}$. Division of this value by the average association rate constant for this site (Table 1, Fig. 3) yielded a $K_{\mathrm{d}}$ of $7.7 \times 10^{-12} \mathrm{M}$, in close agreement with the value $\left(1.0 \times 10^{-11} \mathrm{M}\right)$ derived from steady-state measurements.

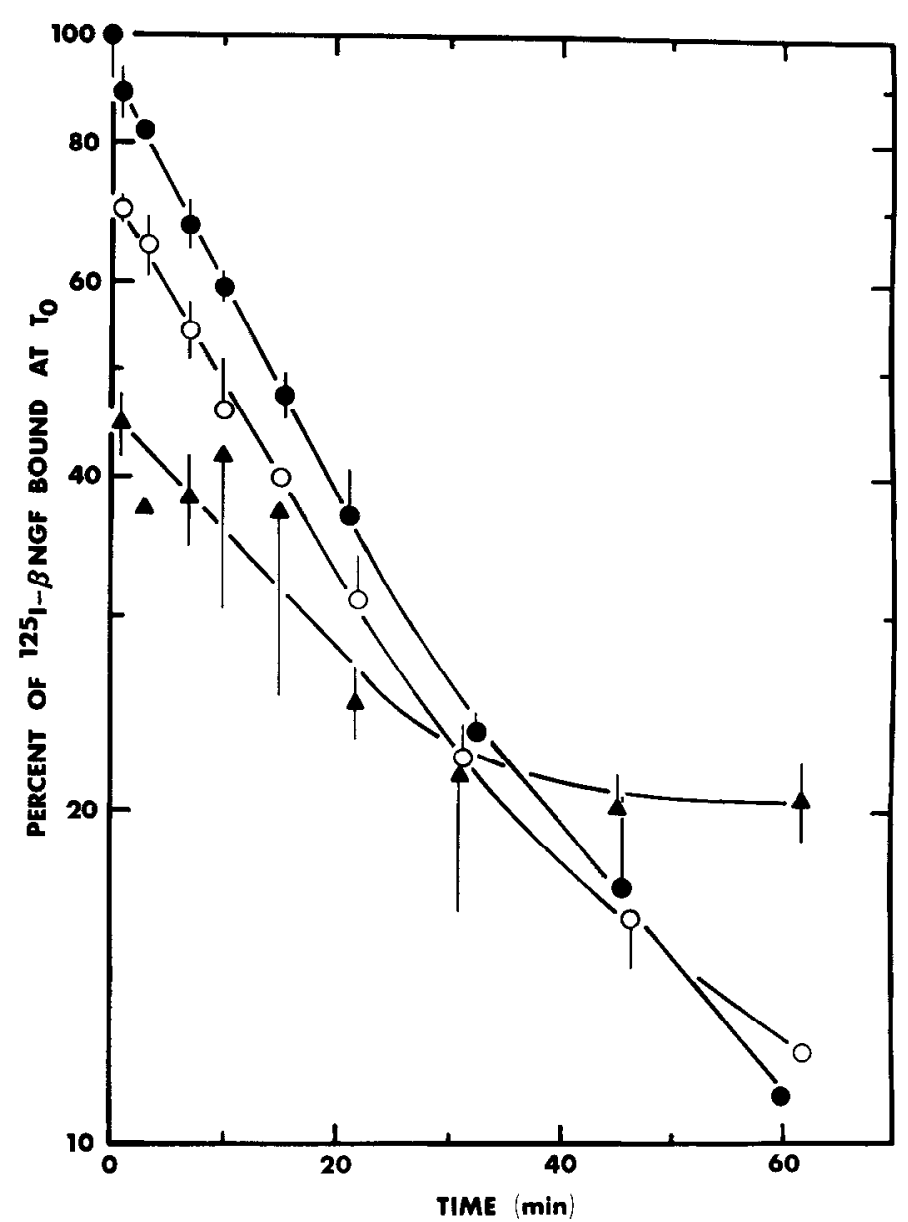

Figure 2. Dissociation of ${ }^{125} \mathrm{I}-\beta$ NGF from chick sympathetic ganglion cells. Cells $\left(1.6-3.2 \times 10^{6} / \mathrm{ml}\right)$ from $11 \mathrm{~d}$ chick embryos were incubated $\left(37^{\circ} \mathrm{C}, 45 \mathrm{~min}\right)$ to steady state with $1.1 \times 10^{-11} \mathrm{M}(0), 5.2 \times 10^{-11} \mathrm{M}$ (O), or $2.6 \times 10^{-9} \mathrm{M}(\Delta){ }^{125} \mathrm{I}-\beta$ NGF. Dissociation was initiated by addition of $1.9 \times 10^{-8} \mathrm{M}(0, \mathrm{O})$ or $1.9 \times 10^{-7} \mathrm{M}(\Delta)$ unlabeled $\beta$ NGF. Samples were taken in quintuplicate immediately before unlabeled $\beta N G F$ was added $\left(t_{0}\right)$, and in triplicate thereafter. Bars indicate SD.

At higher ${ }^{125} \mathrm{I}-\beta \mathrm{NGF}$ concentrations, a second, very rapidly dissociating component became more apparent (Fig. 2, open circles and triangles). This rapid dissociation was complete in $15 \mathrm{sec}$ and, therefore, it was not possible to obtain an accurate dissociation rate constant. The estimate given in Table $1\left(10^{-1}\right.$ $\mathrm{sec}^{-1}$ ) is a minimum value, assuming a half-time for dissociation of $7 \mathrm{sec}$. The dissociation rate constant for the low-affinity site is at lcast 2 ordcrs of magnitude greater than that for the highaffinity site, corresponding to the approximately 100 -fold difference in the $K_{\mathrm{d}}$ of the 2 sites. The fraction of rapidly dissociating ${ }^{125} \mathrm{I}-\beta \mathrm{NGF}$ increased with increasing concentration of ${ }^{125} \mathrm{I}-\beta \mathrm{NGF}$ used for binding, and thus with increasing occupancy of low-affinity receptors. Therefore, the rapidly dissociating component corresponds to ${ }^{125} \mathrm{I}-\beta \mathrm{NGF}$ bound to low-affinity sites.

Two other aspects of dissociation were observed upon closer examination of plots such as that shown in Figure 2. First, there was a very slowly dissociating component of bound ${ }^{125} \mathrm{I}-\beta \mathrm{NGF}$. This component was most easily observed as a plateau in dissociation plots of ${ }^{125} \mathrm{I}-\beta \mathrm{NGF}$ bound at high $\left(2 \times 10^{-9} \mathrm{M}\right)$ concentrations (triangles, Fig. 2). We refer to this component of bound ${ }^{125}$ I- $\beta$ NGF as "sequestered" (Olender and Stach, 1980; Olender et al., 1981), but we do not wish to imply, by using this term, that it is necessarily inaccessible to the external medium (see Discussion). When ${ }^{125}$ I- $\beta$ NGF was bound to cells at this 

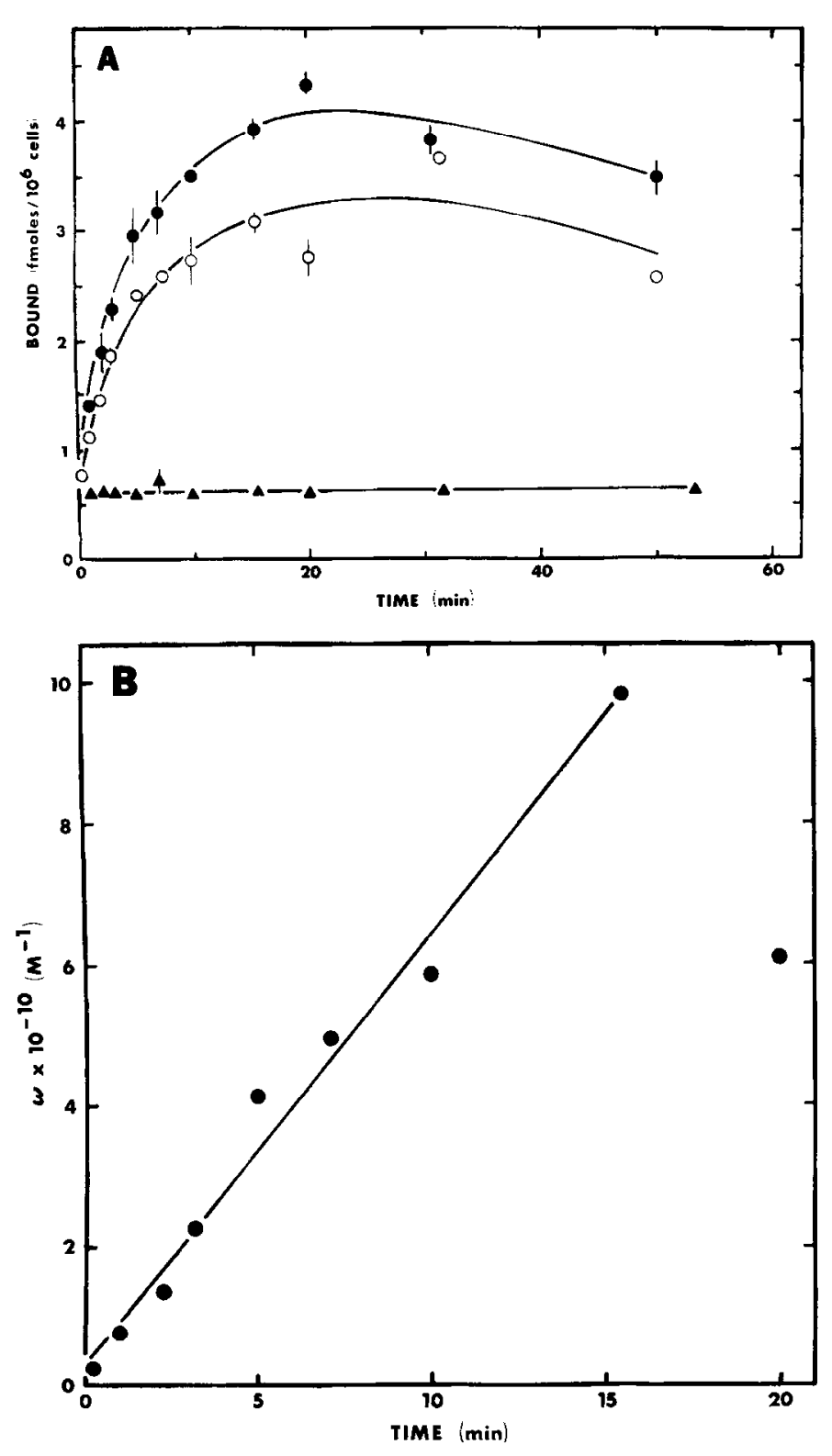

Figure 3. Association of a low concentration $\left(2.3 \times 10^{-11} \mathrm{M}\right)$ of ${ }^{125} \mathrm{I}-$ $\beta N G F$ to sympathetic ganglion cells. Cells $\left(1.5 \times 10^{6} / \mathrm{ml}\right)$ from $11 \mathrm{~d}$ chick embryos were incubated with ${ }^{125} \mathrm{I}-\beta \mathrm{NGF}$ at $37^{\circ} \mathrm{C}$ for various times. $A$, Total ( () , tight ( $O$; see text for definition), and nonspecific $(\Delta)$ binding were measured in triplicate; bars indicate SD. $B$, Tight binding data from $A$ were replotted to obtain $k_{+1}$ for the high-affinity site according to the equation (Shiu and Friesen, 1974) $\omega=k_{+1} t=[\ln (\beta(2 x+\gamma))$ $\gamma(2 x+\beta))] / \sqrt{Q}$ where $Q=D^{2}-4 a b, \beta=D+\sqrt{Q}, \gamma=D-\sqrt{Q} ; D=$ $(-a-b-c) ; a$ is the initial concentration of ${ }^{125}$ I- $\beta$ NGF $(22.9 \mathrm{fmol} /$ $\mathrm{ml}) ; b$ the initial concentration of high-affinity receptors $\left(R_{0}\right.$ from Table $1,5.25 \mathrm{fmol} / \mathrm{ml}) ; c=\left(a-x_{e}\right)\left(b-x_{e}\right) / x_{e}\left(x_{e}=125 \mathrm{I}-\beta N G F\right.$ bound at equilibrium, $4.10 \mathrm{fmol} / \mathrm{ml}$ ); $t$ the time of association (min); and $x$ the [25I- $\beta$ NGF tightly bound at time $t(\mathrm{fmol} / \mathrm{ml})$. The slope yields $k_{+1}$; in this experiment $1.03 \times 10^{8} \mathrm{M}^{-1} \mathrm{sec}^{-1}$.

concentration, $20-60 \%$ of the bound radioactivity was found in the sequestercd compartment. Further, the fraction of bound ${ }^{125}$ I- $\beta$ NGF that was sequestered was highly variable but increased with increasing concentration of ${ }^{125} \mathrm{I}-\beta \mathrm{NGF}$. At low ${ }^{125} \mathrm{I}$ $\beta$ NGF concentrations $\left(1 \times 10^{-11} \mathrm{M}\right.$; Fig. 2 , filled circles $)$, sequestered ${ }^{125}$ I- $\beta$ NGF accounted for less than $10 \%$ of total binding and therefore did not interfere with the determination of the dissociation rate constant for the high-affinity site (Table 1) performed at this concentration. Second, the fraction of slowly dissociating or "tightly bound" ${ }^{25}$ I- $\beta$ NGF (defined in these experiments as the ordinate intercept of the semilog dissociation plot) was greater than that predicted (Catt et al., 1976) for highaffinity binding, using the constants obtained from the steadystate data. At the 3 concentrations of ${ }^{125} \mathrm{I}-\beta \mathrm{NGF}$ used for preequilibration in the experiment of Figure $2,93 \%\left(1.1 \times 10^{-11}\right.$ $\mathrm{M}), 72 \%\left(5.2 \times 10^{-11} \mathrm{M}\right)$, and $46 \%\left(2.6 \times 10^{-9} \mathrm{M}\right)$ tight binding was observed, compared to the predicted values of 75,56 , and $10 \%$ for high-affinity binding at the respective concentrations. The increase in the tight binding component over predicted values was greatest at higher concentrations, and corresponded to the larger fraction of sequestered material seen after binding at higher concentrations of ${ }^{125} \mathrm{I}-\beta \mathrm{NGF}$.

In order to study association of ${ }^{125} \mathrm{I}-\beta \mathrm{NGF}$ to kinetically defined high- and low-affinity receptors, a simple method for separating rapidly dissociating from tightly bound ${ }^{125}$ I- $\beta$ NGF was used (Landreth and Shooter, 1980). Portions of cell suspensions containing ${ }^{125} \mathrm{I}-\beta \mathrm{NGF}$ were removed from incubation mixtures at $37^{\circ} \mathrm{C}$ at various times and added to a large excess of unlabeled $\beta \mathrm{NGF}$ at $0.5^{\circ} \mathrm{C}$. Under these conditions, the rapidly dissociating NGF was removed in less than $5 \mathrm{~min}$, but the fraction of tightly bound material was unchanged and became virtually nondissociable (half-time of $4 \mathrm{hr}$ ). Therefore, in these experiments tight binding was defined as ${ }^{125} \mathrm{I}-\beta \mathrm{NGF}$ remaining bound after 20 $40 \mathrm{~min}$ of dissociation at $0.5^{\circ} \mathrm{C}$. This value was not more than $10 \%$ lower than that obtained from extrapolation to the ordinate of the line fit to the slowly dissociating binding component. This method conveniently measures tightly bound NGF and does not appreciably distort the values obtained from dissociation data at $37^{\circ} \mathrm{C}$.

Association of ${ }^{12 s} \mathrm{I}-\beta$ NGF to its receptors on chick sympathetic ganglion cells and the development of the tightly bound component were followed using the assay just described. At low concentrations of ${ }^{125} \mathrm{I}-\beta \mathrm{NGF}\left(2.3 \times 10^{-11} \mathrm{M}\right)$, most of the binding was tight, as expected from the steady-state results. Steady state was reached between 20 and 50 min of incubation, followed by a slight decrease in both total and tight binding (Fig. $3 A$ ). Since sequestration of bound ${ }^{125} \mathrm{I}-\beta \mathrm{NGG}$ was minimal at this low concentration, tight binding was used as an approximation of binding to the high-affinity site. Analysis of tight binding data using the integrated form of the second-order reversible rate equation (Shiu and Friesen, 1974) yielded a linear plot through the origin (Fig. $3 B$ ) and an average value for the association rate constant of $8.7 \pm 2.3 \times 10^{7} \mathrm{M}^{-1} \mathrm{sec}^{-1}$. Such a large value implies that only diffusion limits the binding of ${ }^{125}$ I- $\beta$ NGF to its highaffinity receptor.

Association to the low-affinity receptor was impossible to measure. If the dissociation rate constant for this site is about $10^{-1} \mathrm{sec}^{-1}$, and the $K_{\mathrm{d}}$ is about $10^{-9} \mathrm{M}$, then the association rate constant should be about $10^{8} \mathrm{M}^{-1} \mathrm{sec}^{-1}$. At the high concentrations of ${ }^{125} \mathrm{I}-\beta \mathrm{NGF}$ needed to assure that most binding occurs at the low-affinity site, one would predict that binding to both classes of receptors would be virtually complete within $1 \mathrm{~min}$. Such an initial rapid phase of association was seen when $1.5 \times$ $10^{-9} \mathrm{M}^{125} \mathrm{I}-\beta$ NGF was bound to cells (Fig. $4 A$ ). However, a slowcr phase of association in both total and tight binding was also seen, which was not complete for about $50 \mathrm{~min}$. When total, tight, or rapidly dissociable binding was replotted according to the second-order reversible rate equation as in Figure $3 B$, fairly linear plots were obtained that intersected the ordinate at points considerably above the origin. Such a plot (for total binding) is shown in Figure $4 B$. These plots confirm the biphasic nature of association to both tight and rapidly dissociating components at high ${ }^{125}$ I- $\beta$ NGF concentrations. The slope of the second phase in these derived plots yielded values of $k_{+1}$ of $10^{4}$ $10^{5} \mathrm{M}^{-1} \mathrm{sec}^{-1}$. These values are 2-3 orders of magnitude too low to account for association to either of the 2 sites observed 

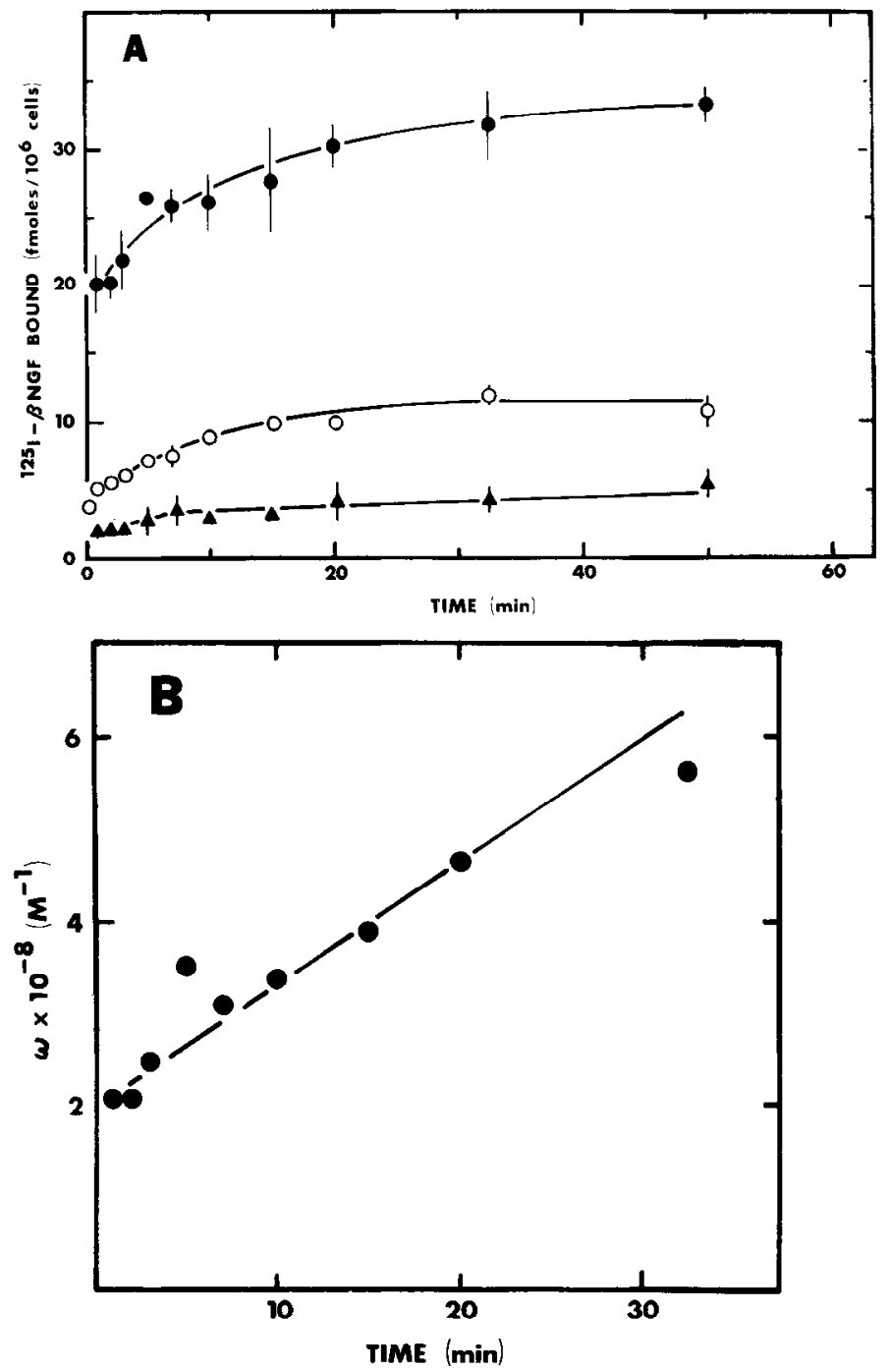

Figure 4. Association of a high concentration $\left(1.5 \times 10^{-9} \mathrm{M}\right)$ of ${ }^{125} \mathrm{I}-$ $\beta N G F$ to sympathetic ganglion cells. Cells $\left(1.4 \times 10^{6} / \mathrm{ml}\right)$ from $11 \mathrm{~d}$ chick embryos were incubated with ${ }^{125} \mathrm{I}-\beta \mathrm{NGF}$ at $37^{\circ} \mathrm{C}$ for various times. $A$, Total (O), tight (O; see text for definition), and nonspecific $(\Delta)$ binding were measured in triplicate; bars indicate SD. $B$, Total binding data from $A$ were replotted as in Figure 3.

in steady-state experiments, and are thus likely to reflect a secondary process subsequent to binding. Association proceeded at similar rates at $0.5^{\circ} \mathrm{C}$, and proportions of tight and rapidly reversible binding similar to those shown in Figure $4 A$ were seen (data not shown).

Data from another kind of experiment also revealed 2 components of tight binding. Tight binding was measured, as described for the association experiments above, after steady state had been reached at various concentrations of ${ }^{125} \mathrm{I}-\beta \mathrm{N}$ NGF. Scatchard plots of total, tight, and rapidly dissociable binding were then made. Tight binding data yielded curvilinear Scatchard plots (Fig. 5, open circles) with 2 components having slopes similar to those of the high-and low-affinity sites seen with Scatchard plots of total binding (Fig. 5, closed circles). Rapidly reversible binding (Fig. 5, triangles) was almost entirely low affinity; the small component that appears to be high affinity is probably an artifact due to the small amount of dissociation of tightly bound NGF that occurs at $0.5^{\circ} \mathrm{C}$.

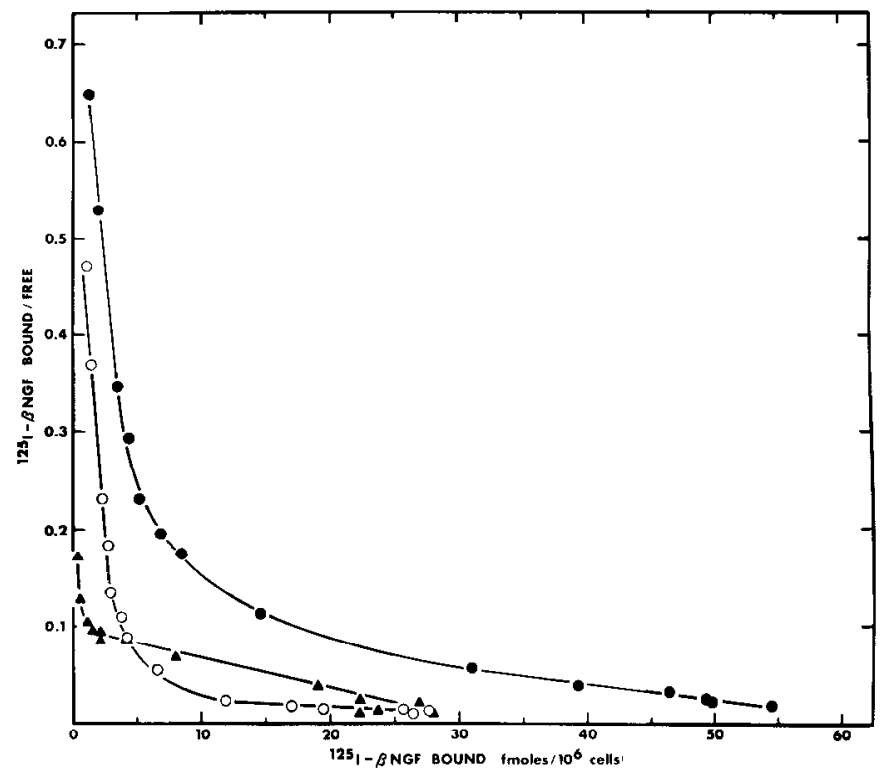

Figure 5. Scatchard plots of total (O), tight $(0)$, and rapidly dissociable (A) binding at steady state. Cells $\left(1.1 \times 10^{6} / \mathrm{ml}\right)$ from $11 \mathrm{~d}$ embryos were incubated $\left(37^{\circ} \mathrm{C}, 45 \mathrm{~min}\right)$ with $3.4 \times 10^{-12}$ to $3.3 \times 10^{-9} \mathrm{M}{ }^{125} \mathrm{I}$ $\beta$ NGF. Aliquots of the incubation mixtures werc then assayed for total and tight binding (see Materials and Methods). Tight binding was measured after dissociation for $20 \mathrm{~min}$ at $0.5^{\circ} \mathrm{C}$ in the presence of a 50 5000 -fold excess of unlabeled $\beta$ NGF. Rapidly dissociable binding was defined as the difference between total and tight binding.

\section{Cooperativity}

Frazier et al. (1974) proposed that the heterogeneity of binding of ${ }^{125}$ I- $\beta$ NGF to chick embryo sympathetic and sensory ganglion cells was due to negatively cooperative interactions among the receptors. According to this hypothesis, increased occupancy of receptors produces a decreased affinity for the ligand. Assuming association rate constants are diffusion limited and do not change with receptor occupancy, this decreased affinity would be reflected in an increasing dissociation rate at increasing occupancies of the receptor. The experimental procedure typically used to detect such an increase in dissociation rate is the "chase versus dilution" experiment. In such an experiment, labeled ligand is allowed to bind to cells until steady state is reached. Dissociation of the labeled ligand is then initiated, either by dilution into ligand-free medium ("dilution" conditions) or by dilution into medium containing a large excess of unlabeled ligand ("dilution plus chase" conditions). Under dilution conditions, the receptor occupancy would not increase, but under dilution plus chase conditions, the large excess of unlabeled ligand would cause a rapid increase in occupancy as it saturated the receptors. If binding is negatively cooperative, the dissociation rate should be accelerated under dilution plus chase conditions, and the magnitude of the increase should be similar to that of the difference in apparant $K_{\mathrm{d}}$ at low and high ligand concentrations.

Results of chase versus dilution experiments are shown in Figure 6. Cells were incubated to steady state with $5 \times 10^{-12} \mathrm{M}$ ${ }_{125}$ I- $\beta$ NGF, then diluted 15 -fold into buffer with or without unlabeled $\beta$ NGF. This dilution factor was sufficient to prevent significant rebinding of dissociated label during the initial phases of dissociation. When a large excess (1500-fold) of unlabeled $\beta N G F$ was used in chase plus dilution conditions, the dissociation rate was increased (Fig. $6 \mathrm{~A}$ ). However, a similar, though smaller, acceleration of dissociation was also seen when the concentration of unlabeled $\beta$ NGF in chase plus dilution conditions was lower than that of the ${ }^{125} I-\beta N G F$ used for preloading (Fig. 6B). In other words, the rate of dissociation was increased 

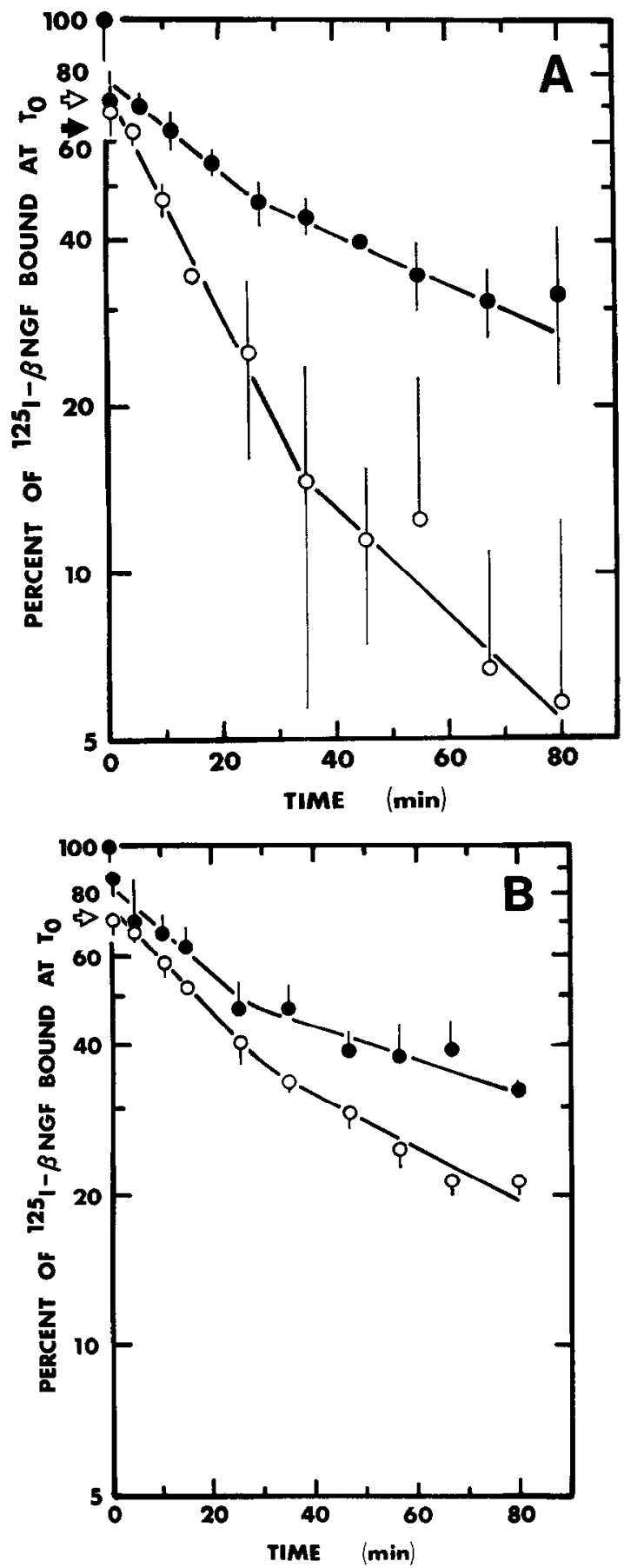

Figure 6. Dissociation kinetics of bound ${ }^{125}$ I- $\beta$ NGF from chick sympathetic ganglion cells under dilution and dilution plus chase conditions. $A, \beta$ NGF chase concentration was greater than ${ }^{125}$ I- $\beta$ NGF preloading concentration. Cells $\left(3.0 \times 10^{6} / \mathrm{ml}\right)$ from $11 \mathrm{~d}$ chick embryos were in-

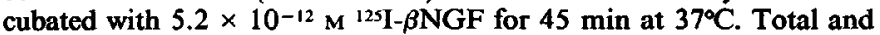
nonspecific binding were then measured in quadruplicate without dilution ( $t_{0}$ values). Dissociation was initiated by dilution of $0.1 \mathrm{ml}$ portions of cell suspension into $1.4 \mathrm{ml}$ PBS plus $1 \mathrm{mg} / \mathrm{ml} \mathrm{BSA}$ at $37^{\circ} \mathrm{C}$, with (O) or without (O) $7.7 \times 10^{-9} \mathrm{M}$ unlabeled $\beta N G F$. Quadruplicate samples were taken; bars indicate SD. $B, \beta N G F$ chase concentration was less than ${ }^{125} \mathrm{I}-\beta \mathrm{NGF}$ preloading concentration. Cells $\left(2.2 \times 10^{6} \%\right.$ $\mathrm{ml}$ ) were incubated with ${ }^{125} \mathrm{I}-\beta \mathrm{NGF}$ as in $A$. Dissociation was followed after dilution (as in $A$ ) either with $(O)$ or without $(0) 1.5 \times 10^{-12} \mathrm{M}$ unlabeled $\beta$ NGF. Arrows along the ordinates indicate amounts tightly bound after addition of a large excess of unlabeled $\beta$ NGF (chase) at $0.5^{\circ} \mathrm{C}$ without any dilution. by unlabeled $\beta \mathrm{NGF}$, and this occurred whether the receptor occupancy was increased or decreased. Furthermore, the increase in dissociation rate (a doubling with a 1000- to 1500fold excess of unlabeled $\beta \mathrm{NGF}$ ) is insufficient to account for the 100 -fold difference in apparent $K_{\mathrm{d}}$. Thus, negative cooperativity cannot explain the heterogeneity of ${ }^{125} \mathrm{I}-\beta \mathrm{NGF}$ binding seen in both steady state and kinetic experiments.

\section{Cellular and developmental aspects}

Development of NGF receptors was examined using sympathetic ganglion cells from embryos at $61 / 2-20 \mathrm{~d}$ of incubation. Scatchard plots of steady-state binding data revealed both lowand high-affinity components at all 11 stages examined. Several experiments were performed at each of the following ages: 9, 11 , and 15 days in ovo. No significant difference $(p>0.1)$ was found in $K_{\mathrm{d}}$ or number of receptors per cell, for either of the 2 sites, at these stages (Table 2).

Cultures of non-neuronal cells from sympathetic ganglia were obtained from cells adhering to collagen-coated dishes during a preplating step, as described in Materials and Methods. The cells that attached to the preplates were almost exclusively nonneuronal (i.e., they were not phase bright and did not have long, thin processes). Any remaining neurons were lost after subculturing these cells 2-4 times. Scatchard plots of binding data obtained with these non-neuronal cells showed no detectable high-affinity component, although a large number of low-affinity receptors ( $>10^{s}$ per cell) were present (data not shown). Competition curves using $7.7 \times 10^{-10} \mathrm{M}$ 125 I- $\beta \mathrm{NGF}$ and increasing concentrations of unlabeled $\beta \mathrm{NGF}$ also showed a low-affinity site with a $K_{\mathrm{d}}$ of about $10^{-9} \mathrm{M}$ on these non-neuronal cells (data not shown). The binding data were similar if the non-neuronal cells had been cultured in the presence of $\beta \mathrm{NGF}\left(7.7 \times 10^{-10}\right.$ M).

\section{Discussion}

Three major conclusions can be drawn from the results presented here. First, there are at least 2 classes of receptors for NGF on chick sympathetic ganglion cells; these 2 classes are similar to those found on chick sensory ganglion cells and differ in their affinity for NGF by about 2 orders of magnitude. Second, in addition to the reversible binding to these 2 classes of receptors, some of the NGF bound at high concentrations is very slowly dissociable. Third, there is little change in the steadystate binding characteristics of NGF receptors on sympathetic ganglion cells during development from 9 to $15 \mathrm{~d}$ of incubation; both high- and low-affinity receptors are present from 6.5 to 20 $\mathrm{d}$ of development.

The simplest and most consistent interpretation of the steadystate and kinetic binding data presented here is that there are 2 classes of NGF receptors on cells of chick embryo sympathetic ganglia. Scatchard plots of steady-state data are biphasic, and plots of bound versus free ligand concentration can be fit well by curves generated from a 2-site model. Kinetic data confirm this interpretation. Dissociation of bound ${ }^{125}$ I- $\beta$ NGF was essentially a biphasic process. The fraction of rapidly dissociable (low-affinity bound) ${ }^{125}$ I- $\beta$ NGF increascd with increasing concentrations of ${ }^{125} \mathrm{I}-\beta \mathrm{NGF}$. The association and dissociation rate constants obtained from the kinetic data agree well with the affinity constants obtained from fitting the 2-site model to the steady-state data. Despite the presence of a substantial, very slowly dissociating component of bound NGF ("sequestered" NGF) at high preloading concentrations, the 2-site model provides a useful, consistent first approximation to describe these NGF receptors (see below).

Negatively cooperative interactions between NGF receptors (Frazier et al., 1974) cannot explain the heterogeneity of NGF binding. Biphasic dissociation kinetics are inconsistent with such 
Table 2. Steady-state binding constants during development

\begin{tabular}{|c|c|c|c|c|c|}
\hline \multirow{2}{*}{$\begin{array}{l}\text { Age of } \\
\text { embryos } \\
\text { (d) }\end{array}$} & \multicolumn{2}{|c|}{ High-affinity receptors ${ }^{b}$} & \multicolumn{2}{|c|}{ Low-affinity receptors ${ }^{b}$} & \multirow[b]{2}{*}{$n$} \\
\hline & $\begin{array}{l}\text { Sites per } \\
\text { cell }\end{array}$ & $\begin{array}{l}\text { Affinity constant } \\
\text { (M) }\end{array}$ & $\begin{array}{l}\text { Sites per } \\
\text { cell }\end{array}$ & $\begin{array}{l}\text { Affinity constant } \\
\text { (M) }\end{array}$ & \\
\hline 9 & $2500 \pm 2200$ & $4.9 \pm 4.1 \times 10^{-11}$ & $67,000 \pm 47,000$ & $4.4 \pm 2.2 \times 10^{-9}$ & 2 \\
\hline 11 & $4000 \pm 3500$ & $3.0 \pm 3.5 \times 10^{-11}$ & $38,000 \pm 27,000$ & $1.8 \pm 1.8 \times 10^{-9}$ & 7 \\
\hline 15 & $2800 \pm 1050$ & $1.1 \pm 0.4 \times 10^{-10}$ & $57,000 \pm 28,000$ & $3.3 \pm 3.1 \times 10^{-8}$ & 5 \\
\hline
\end{tabular}

${ }^{a}$ Ganglia from 9 and $11 \mathrm{~d}$ embryos were dissociated with $0.01 \%$ trypsin; those from $15 \mathrm{~d}$ embryos required $0.1 \%$ trypsin for dissociation (sec Rcsults). Stcady-state binding constants are averages ( $(\mathrm{SD})$ of constants derived from computer fits of a 2-site model to steady-state binding data (see legend of Table 1).

${ }^{b}$ Constants obtained from experiments with 9,11 , and $15 \mathrm{~d}$ embryos are not significantly different (Student's $t$ test, $p>$ $0.1)$.

an interpretation. Both phases were present at all concentrations of ${ }^{125} \mathrm{I}-\beta \mathrm{NGF}$ used for preloading, and the proportions of the 2 phases depended on the prcloading concentration and not on the concentration of unlabeled NGF present during dissociation (Figs. 2, 6). In addition, only a 2 -fold increase in the dissociation rate was seen under dilution plus chase conditions, as compared to dilution alone. This increased dissociation rate cannot account for the 100 -fold difference in apparent $K_{\mathrm{d}}$; furthermore, the increase was seen whether receptor occupancy during dissociation was increased or decreased. Thus, dissociation rates did not depend on receptor occupancy, ruling out the negative cooperativity model.

Closer examination of the kinetic data reveals additional complexity in the system. In addition to the 2 classes of receptors that bind NGF reversibly, there is a component of NGF bound at high preloading concentrations that is very slowly dissociable or "sequestered." At least 4 observations could reflect this component of bound NGF. First, there was a plateau in dissociation plots (Fig. 2, triangles). The fraction of bound ${ }^{125} \mathrm{I}-\beta \mathrm{NGF}$ that was sequestered increased with increasing ${ }^{125} \mathrm{I}-\beta \mathrm{NGF}$ concentration, being minimal $(<10 \%)$ at concentrations up to $1.5 \times$ $10^{-10} \mathrm{M}$ but reaching values as high as $20-60 \%$ at an ${ }^{125} \mathrm{I}-\beta \mathrm{NGF}$ concentration of $1.5 \times 10^{-9} \mathrm{M}$. Second, the fraction of tightly bound NGF was larger than predicted from the steady-state binding constants. Third, association kinetics of tightly bound material were monophasic at low ${ }^{12 s} I-\beta N G F$ concentrations, but a second, slower, phase appeared at high preloading concentrations-conditions under which low-affinity binding becomes significant. Fourth, Scatchard plots of tight binding were biphasic (Fig. 5), with a prominent low-affinity component that probably corresponds to sequestered bound NGF. Similar results have been seen with sensory ganglion cells from chick embryos (Sutter, 1981). All these observations have led us to propose that the very slowly dissociating, sequestered component of bound NGF initially binds largely to low-affinity receptors. This hypothesis explains the concentration dependence of sequestration and the presence of the low-affinity component of tight binding on Scatchard plots.

The molecular basis and functional significance of sequestration are unclear. Internalization of NGF leading to its degradation in lysosomes has been demonstrated in both chick sensory ganglion cells and PC12 cells (Layer and Shooter, 1983; Sutter et al., 1979a). A small amount of degradation was also observed in chick sympathetic ganglion cells; thus, some of the bound ${ }^{125} I-\beta N G F$ could have been internalized via pinocytosis or receptor-mediated endocytosis. Artifacts of handling could also have contributed to sequestration, since it was quite variable. Although every effort was made to standardize the preparation of the cell suspension, such factors as recovery from trypsinization and incubation in BSA-containing buffer could have contributed to this phenomenon. Olender and Stach (1980) suggest that sequestration is probably not internalization, since they observed it at $4^{\circ} \mathrm{C}$, a condition under which internalization should be blocked (Bernd and Greene, 1984). Although we did not measure sequestration after NGF binding at $0.5^{\circ} \mathrm{C}$, we did not observe a decrease in the number of low-affinity binding sites or in the proportion of tightly bound NGF at that temperature, consistent with their findings. It is not possible to resolve the question of the localization of sequestered NGF on the basis of NGF binding data alone. Other approaches, such as electron microscope autoradiography and differential release of surface-bound NGF (e.g., Bernd and Greene, 1984), will be required to define the localization and function of the various components of bound NGF.

It is important to emphasize, first, that sequestration, although it can account for a large portion of NGF binding at high ${ }^{125} \mathrm{I}-$ $\beta$ NGF concentrations, is probably not physiologically relevant, since it becomes significant only at concentrations above $10^{-10}$ M. These levels are above the saturation point for the highaffinity receptor, which is thought to mediate the initiation of neurite outgrowth from responsive neurons (Sutter et al., 1979b), and are probably never encountered by a developing sympathetic neuron in vivo. Second, this phenomenon is seen in a mixed population of cells; it is possible that the cells that sequester NGF are different from those that have the high- and low-affinity receptors. This could be tested using purified neuronal and non-neuronal cells. Third, the presence of this slowly dissociating component does not invalidate the use of a steadystate model to measure the 2 classes of cell surface receptors. Since it is seen only at high concentrations, it does not affect estimates of the number, affinity, or kinetic constants of the high-affinity receptors. It probably causes an overestimation of the number of low-affinity sites by as much as a factor of 2 , due to the large amount of tightly bound NGF seen in the lowaffinity component of Scatchard plots (Fig. 5), although the $K_{\mathrm{d}}$ for these sites is probably not distorted much, since the slope of the rapidly reversible low-affinity component is similar to that of the low-affinity portion of the Scatchard plot of total binding. This complexity indicates that the steady-state, 2-site model approximates but does not completely explain the interaction of NGF with sympathetic ganglion cells.

Both high- and low-affinity receptors were present on sympathetic ganglion cells from chick embryos at 6.5-20 d of development. These findings are consistent with those of Rohrer et al. (1983), who showed, by autoradiography of ${ }^{125} \mathrm{I}-\beta \mathrm{NGF}$ bound to cultured cells, that all chick embryo sympathetic neurons had high-affinity NGF receptors at 7,12 , and $16 \mathrm{~d}$ of incubation. We were unable to define the time of appearance of high- and low-affinity NGF receptors on these cells, since we could not remove ganglia from embryos younger than $6.5 \mathrm{~d}$ because they were too small. The numbers and affinities of receptors on the cell bodies appeared to change little during the period of development we examined. This is not surprising, since neurite outgrowth from secondary sympathetic ganglia has 
been observed in vivo as early as $5.5 \mathrm{~d}$ (Kirby and Gilmore, 1976), and monoaminergic processes were seen in target organs as early as day 8 (Enemar et al., 1965). It is likely that NGF receptors on the neurites are more numerous and more important for sustaining neurite outgrowth than those on the cell bodies (Campenot, 1982; Claude et al., 1982); however, we assume that binding data obtained with cell bodies reflect the characteristics of NGF receptors on neurites as well.

Non-neuronal cells from sympathetic ganglia were cultured with or without added $\beta$ NGF in the medium. These cells possessed only the low-affinity NGF receptors. This result is similar to that seen with non-neuronal cells from chick sensory ganglia (Sutter et al., 1979b; Zimmermann and Sutter, 1983). It is assumed from the results with cultured non-neuronal cells that high-affinity NGF receptors are found only on neurons in the sympathetic ganglia in vivo, as is the case with chick sensory ganglia (Sutter et al., 1979b); however, this assumption was not tested.

The NGF receptors described here appear to be very similar to those described for chick sensory ganglion cells. The kinetic and steady-state data obtained by Sutter et al. (1979a) for sensory ganglion cells and the constants derived from the data are very similar to those obtained in the present study. More recent data (Olender et al., 1981) show that sequestration also occurs in sensory ganglion cells. The only known difference between the NGF receptors in these 2 types of NGF-responsive cells is in their development. In sensory ganglia, the number of NGF receptors per cell appears to be greatly reduced after embryonic day 16; this correlates well with a decreased responsiveness to NGF (Barde et al., 1980; Greene, 1977a; Herrup and Shooter, 1975). In chick sympathetic ganglia, however, the number of NGF receptors per cell does not appear to change appreciably during most of embryonic development. Similarly, some chick sympathetic neurons continue to require NGF for neurite outgrowth and survival through late embryonic life (Edgar and Thoenen, 1982; Greene, 1977b).

\section{References}

Barde, Y.-A., D. Edgar, and H. Thoenen (1980) Sensory neurons in culture: Changing requirements for survival factors during embryonic development. Proc. Natl. Acad. Sci. USA 77: 1199-1203.

Bernd, P., and L. A. Greene (1984) Association of ${ }^{125}$ I-nerve growth factor with $\mathrm{PC} 12$ pheochromocytoma cells: Evidence for internalization via high-affinity receptors only and for long-term regulation by NGF of both high- and low-affinity receptors. J. Biol. Chem. 259: 15509-15516.

Campenot, R. B. (1982) Development of sympathetic neurons in compartmentalized cultures. I. Local control of neurite outgrowth by nerve growth factor. Dev. Biol. 93: 1-12.

Catt, K., J.-M. Ketelslegers, and M. L. Dufau (1976) Receptors for gonadotropic hormones. In Methods in Receptor Research, Pt. 1, M. Blecher, ed., pp. 175-250, Dekker, New York.

Claude, P., E. Hawrot, D. A. Dunis, and R. B. Campenot (1982) Binding, internalization, and retrograde transport of ${ }^{225}$ I-nerve growth factor in cultured rat sympathetic neurons. J. Neurosci. 2; 431-442.

Dulbecco, R., and M. Vogt (19\$4) Plaque formation and isolation of pure lines with poliomyelitis virus. J. Exp. Med. 99: 167-199.

Edgar, D., and H. Thoenen (1982) Modulation of NGF-induced survival of chick sympathetic neurons by contact with a conditioned medium factor bound to the culture substrate. Dev. Brain Res. 5: 8992.

Edgar, D., Y.-A. Barde, and H. Thoenen (1981) Subpopulations of cultured chick sympathetic neurones differ in their requirements for survival factors. Nature 289: 294-295.

Enemar, A., B. Falck, and R. Håkanson (1965) Observations on the appearance of norepinephrine in the sympathetic nervous system of the chick embryo. Dev. Biol. 11: 268-283.

Frazier, W. A., L. F. Boyd, and R. A. Bradshaw (1974) Properties of the specific binding of ${ }^{125}$ I-nerve growth factor to reponsive peripheral neurons. J. Biol. Chem. 249: 5513-5519.
Godfrey, E. W., and F. M. Shnoter (1979) Nerve growth factor receptors on chick sympathetic ganglion cells. Soc. Neurosci. Abstr. 5: 767.

Greene, L. A. (1977a) Quantitative in vitro studies on the nerve growth factor (NGF) requirements of neurons. II. Sensory neurons. Dev. Biol. 58: 106-113.

Greene, L. A. (1977b) Quantitative in vitro studies on the nerve growth factor (NGF) requirements of neurons. I. Sympathetic neurons. Dev. Biol. 58: 96-105.

Greene, L. A., and E. M. Shooter (1980) The nerve growth factor: Biochemistry, synthesis, and mechanism of action. Annu. Rev. Neurosci. 3: 353-402.

Hamilton, H. (1952) Lillie's Development of the Chick: An Introduction to Embryology, Henry Holt, New York.

Herrup, K., and E. M. Shooter (1973) Properties of the $\beta$-nerve growth factor receptor on avian dorsal root ganglia. Proc. Natl. Acad. Sci. USA 70: 3884-3888.

Herrup, K., and E. M. Shooter (1975) Properties of the $\beta$-nerve growth factor receptor in development. J. Cell Biol. 67: 118-125.

Hosang, M., and E. M. Shooter (1985) Molecular characteristics of nerve growth factor receptors on PC12 cells. J. Biol. Chem. 260:655662.

Kirby, M. L., and S. A. Gilmore (1976) A correlative histofluorescence and light microscopic study of the formation of sympathetic trunks in chick embryos. Anat. Rec. 186: 437-450.

Landreth, G. E., and E. M. Shooter (1980) Nerve growth factor receptors on PC1 2 cells: Ligand-induced conversion from low- to highaffinity states. Proc. Natl. Acad. Sci. USA 77: 4751-4755.

Layer, P. G., and E. M. Shooter (1983) Binding and degradation of nerve growth factor by $\mathrm{PCl} 2$ pheochromocytoma cells. J. Biol. Chem. 258: 3012-3018.

Moore, J. B., Jr., and E. M. Shooter (1975) The use of hybrid molecules in a study of the equilibrium between nerve growth factor monomers and dimers. Neurobiology 5: 369-381.

Olender, E. J., and R. W. Stach (1980) Sequestration of ${ }^{125}$ I-labeled $\beta$ nerve growth factor by sympathetic neurons. J. Biol. Chem. 255 . 9338-9343.

Olender, E. J., B. J. Wagner, and R. W. Stach (1981) Sequestration of ${ }^{125}$ I-labeled $\beta$ nerve growth factor by embryonic sensory neurons. J. Neurochem. 37: 436-442.

Riopelle, R. J., M. Klearman, and A. Sutter (1980) Nerve growth factor receptors: Analysis of the interaction of NGF with membranes of chick embryo dorsal root ganglia. Brain Res. 199: 63-77.

Rohrer, H., H. Thoenen, and D. Edgar (1983) Presence of nerve growth factor receptors and catecholamine uptake in subpopulations of chick sympathetic neurons: Correlation with survival factor requirements in culture. Dev. Biol. 99: 34-40.

Scatchard, G. (1949) The attractions of proteins for small molecules and ions. Ann. NY Acad. Sci. 51: 660-675.

Shiu, R. P. C., and H. G. Friesen (1974) Properties of a prolactin receptor from the rabbit mammary gland. Biochem. J. 140:301-311.

Spooner, B. S. (1970) The expression of differentiation by chick embryo thyroid in culture. I. Functional and fine structural stability in mass and clonal culture. J. Cell. Physiol. 75: 33-48.

Sutter, A. (1981) Characteristics of nerve growth factor receptors by ligand binding studies. Hoppe Seylers Z. Physiol. Chem. 362: 13001301.

Sutter, A., R. J. Riopelle, R. M. Harris-Warrick, and E. M. Shooter (1979a) Nerve growth factor receptors. Characterization of two distinct classes of binding sites on chick embryo sensory ganglia cells. J. Biol. Chem. 254: 5972-5982.

Sutter, A., R. J. Riopelle, R. M, Harris-Warrick, and E. M. Shooter (1979b) The heterogeneity of nerve growth factor receptors. In Transmembrane Signaling, M. Bitensky, R. J. Collier, D. F. Steiner, and C. F. Fox, eds., pp. 659-667, Liss, New York.

Thoenen, H., and Y.-A. Barde (1980) Physiology of nerve growth factor. Physiol. Rev. 60: 1284-1334.

Yankner, B. A., and E. M. Shooter (1982) The biology and mechanism of action of nerve growth factor. Annu. Rev. Biochem. 51:845-868.

Zimmermann, A., and A. Sutter (1983) $\beta$-Nerve growth factor ( $\beta N G F)$ receptors on glial cells. Cell-cell interaction between neurones and Schwann cells in cultures of chick sensory ganglia. EMBO J. 2: 879885. 